Journal of Economic Theory 4 (2): 50-58, 2010

ISSN: 1994-8212

(C) Medwell Journals, 2010

\title{
An Empirical Analysis of Causality Between Financial Development Economic Growth: Further Evidence from Sub-Saharan Africa
}

\author{
T. Egbetunde and H.I. Mobolaji \\ Department of Economics and Financial Studies, Fountain University, Osogbo, Nigeria
}

\begin{abstract}
The study examines the long run and causal relationship between financial development and economic growth for ten countries in sub-Saharan Africa. Using the Vector Error Correction Model (VECM), the study finds that financial development is co-integrated with economic growth in all selected ten countries in Sub-Saharan Africa. Moreover, this test supports the estimated coefficient of the error correction terms found statistically significant with a negative sign which confirmed that there was not any problem in long run equilibrium between financial development and economic growth in the countries. Granger causality based on multivariate VECM further shows that financial development Granger causes economic growth in Burundi, Cameroon, Mali and Nigeria while economic growth Granger causes financial development in Benin, Burkina Faso, Madagascar and Malawi. Within the same framework, the evidence of bidirectional causality shows between financial development and economic growth in Cote d'Ivoire and Ghana. Based on these results, the study argues that financial development could help promote economic growth in four countries while economic growth could help promote financial development in four countries and financial development and economic growth promote one another in 2 countries. However, to achieve these goals, financial markets need to be further developed through appropriate regulatory and macroeconomic policies which in turn accelerate economic growth in Sub-Saharan Africa.
\end{abstract}

Key words: Financial development, economic growth, goal, macroeconomic policies, Sub-Saharan Africa

\section{INTRODUCTION}

The relationship between financial development and economic growth still remains a controversial issue in the literature. The question is whether financial development causes economic growth or vice versa. There are 3 basic hypotheses on the causal relationship between financial sector development and economic growth. These are finance-led growth, growth-led finance and feedback hypothesis.

The finance-led growth hypothesis postulates the supply leading relationship between financial development and economic growth. Financial development is seen as contributing to economic growth in the following ways; pooling and trading of risks; acquisition of information ex-ante, ex-post monitoring of management and exertion of corporate control; efficient saving mobilization and increased specialization in production, developments of entrepreneurship and adoption of new technology.

Several studies have confirmed the positive impact of financial development on economic growth. Empirical evidence in support of finance-led growth includes Schumpeter (1911), Levine (1997). King and Levine (1993), Arestis et al. (2001), Athanasios and Antonoios (2009), Abu-Bader and Abu-Quan (2005). In contrast, the growth- led hypothesis otherwise called demand following thesis states that a high economic growth may create demand for certain financial instruments and arrangements and the financial markets are effectively responsive to these demands and changes.

Essentially according to this view, financial development is seen as the handmaiden of economic development, reacting positively to the demand for new financial services by a growing economy. The development in the financial sector is facilitated by the growth in the real sector of the economy. The impact of economic growth on financial development has been documented in Robinson (1952) and Odhiambo (2008).

The third view called the feedback hypothesis, recognizes a two-way relationship between financial development and economic growth. In this hypothesis, it is asserted that a country with a well-developed financial system could promote high economic expansion through technical changes and products and services innovation (Schumpeter, 1911).

This in turn will create high demand on financial arrangements and services (Levine, 1997). As banking institutions effectively respond to these demands, these changes will stimulate a higher economic growth. Thus, both financial development and economic growth are positively interdependent and their relationship could

Corresponding Author: T. Egbetunde, Department of Economics and Financial Studies, Fountain University, Osogbo, Nigeria 
lead to feedback causality. A number of studies have provided empirical evidence supporting this view such as Luintel and Khan (1999), Patrick (1966), Wolde-Rufael (2009) and Al-Yousif (2002).

Moreover, Patrick's hypothesis highlights the twoway causality which may exist between financial development and growth. It is, however incomplete as it does not take the complementary of the 2 phenomena into account. While supply-leading financial development can in fact speed up economic growth, demand-following financial development is not just a passive adaptation of the financial system to the development requirements of the real sector. On the contrary, real growth enables the financial system to accomplish its own autonomous evolution since, the sustained increase in real income provides the means to set up a costly and increasingly sophisticated financial intermediation.

The financial sector by identifying creditworthy firms, pooling risks, mobilizing savings and allocating capital without loss via moral hazard, adverse selection or transaction costs is important for the economic development of an economy. Levine (1997) categorizes the function of a financial system into five basic tasks which include financial system facilitate the trading, hedging, diversifying and pooling of risk, allocate resources, monitoring managers and exerting corporate control, mobilizing savings and facilitate the exchange of goods and services.

There is however, considerable debate on the exact channels through which financial development induces economic growth. The theorists can be subdivided into 2 broad schools of thought: the structuralists and the repressionists. The structuralists contend that the quality and composition of financial variables induce economic growth by directly increasing saving in the form of financial assets, thereby, encouraging capital formation and hence, economic growth (Goldsmith, 1969; Gurley and Shaw, 1955; Patrick, 1966). Thus, factors such as financial deepening (i.e., depth and size of aggregate financial assets relative to GDP) and the composition of the aggregate financial variables are important for economic growth. For example, Kwan shows that financial deepening has had a positive impact on output growth, using exogeneity tests for several high performing Asian countries.

The financial repressionists, led by Mckinnon (1973) and Shaw (1973) often referred to as the Mckinnon-Shaw hypothesis contend that financial liberalization in the forms of an appropriate rate of return on real cash balances is a vehicle of promoting economic growth. The essential tenet of this hypothesis is that a low or negative real interest rate will discourage saving. This will reduce the availability of loanable funds for investment which in turn will lower the rate of economic growth. Thus,
Mckinnon-Shaw model posits that a more liberalized financial system will induce an increase in saving and investment and therefore, promote economic growth. Ahmad and Ansari investigated the Mckinnon-Shaw hypothesis for Bangladesh and found some, although weak support for their hypothesis.

They focus on price variables as the relevant financial factors for growth. Khan and Hassan (1998) in a recent study for Pakistan found strong support for the Mckinnon-Shaw hypothesis. Also this hypothesis was explored in the research of Galbis (1977), Mathieson (1980), Fry (1988) and Roubini and Sala-i-Martin (1992). However, the structuralist and the repressionist have a common underlying thread that is; the efficient utilization of resources enhances economic growth. This is achieved via a highly organize, developed and liberated financial system.

It is clear that if causality can be established from financial sector development to economic growth or reversely then these studies have direct policy implications. The literature implies that a more efficient financial system will enable an economy to increase in real GDP growth rate. Thus, establishing appropriate financial sector policies is of paramount importance to policymakers.

It is argued that these policies can ameliorate market failures by the provision of services that facilitate transactions, mobilize capital and exert corporate governance; thereby enhancing economic growth. This study investigates the relative contribution of financial development to economic growth using data from 10 countries in Sub-Saharan Africa since, 1970-2005. The objectives of this study are to examine effects of financial indicators on per capita GDP (Gross Domestic Product) and secondly, to examine multivariate causality between financial development indicators and economic growth in 10 selected Sub-Saharan Africa. This may enhance effective policy formation in the region.

Financial development and growth: The relationship between financial development and economic growth has generated so much controversy over the last 5 decades. The studies of McKinnon (1973), Goldsmith (1969) and Shaw (1973) report a positive correlation between financial development and economic growth. A different view of finance-growth nexus shows that there is negative relationship between financial development and economic growth in developing economies.

Deidda and Fattouh (2002), Rioja and Valev (2003) and $\mathrm{Xu}$ (2000) support this view from the findings of their studies. Townsend (1979), Diamond (1984) and Boyd and Prescott (1986) emphasize the impact of financial development on economic growth. While others, such as 
Robinson (1952) and Patrick (1966) explain the channel of effect from growth to finance. Based on traditional growth theory, financial development could be related to the level of per capita income, through the level of physical capital per worker or the level of productivity. However, no relationship between financial development and economic growth has been found based on traditional growth theory. In endogenous growth theory not only a level of effect but also a growth effect could be identified as a consequence of financial development.

Recently, Levine and Renelt (1992) have examined the relationship between financial development and economic growth in a model in which variables such as the initial level of per capita income, the human capital measures trade, etc. were also included. They have shown that the positive correlation between financial development and economic growth still exist. King and Levine (1993), Levine and Zervos (1998) and Neusser and Kugler (1998) have further shown that the level of financial development is a good predictor of the future economic growth. Levine et al. (2000) using the Generalized Method of Moments (GMM) dynamic panel estimators have shown that the exogenous components of financial intermediary development are positively associated with economic growth.

As mentioned by Levine (1997), the cost of acquiring information and making transactions, create incentives for the emergence of financial markets and institutions'. This indicates that in a world of Arrow (1964) and Debreu (1959) which is characterized by no information or transaction costs, there will be no incentive for the creation of a financial system. Allocation of resources, mobilization of savings, facilitating the exchange of goods and services, monitoring managers and facilitating the trading, hedging, diversifying and pooling of risk are the main functions of the financial intermediary systems.

Moreover, a large number of studies that discussed on the direction of causality between financial development and economic growth are divided into 3 views. The first view contends that financial development granger causes economic growth McKinnon (1973), Shaw (1973) and Levine (1997) argue along this line. While the second view asserts that growth granger causes financial development. Chandavarkar (1992) and Robinson (1952) report that growth led finance.

The third view argues that bi-directional causality exists between financial development and economic growth. Patrick (1966) and Luintel and Khan (1999) support this view from their findings. To capture the potential effects of financial development on economic growth therefore, following Pagano (1993), the study considers the AK model as a simple endogenous growth model where aggregate output is a linear function of the aggregate capital stock, such as Eq. 1:

$$
\mathrm{Y}_{\mathrm{t}}=\mathrm{A} \mathrm{K}_{\mathrm{t}}
$$

Equation 1 provides the relationship between output and capital at the aggregate level. The relationship could be justified by the aggregation of the production activities at the firm level with an aggregate externality coming from the aggregate capital, such as Romer (2001). It can also be the result of considering the capital $\mathrm{K}$ as a composite of physical and human capital such as Lucas (1988). For simplicity, assume that the population is stationary and that the economy produces a single good that can be invested or consumed and if invested, depreciate at the rate $(\delta)$ per period. Gross investment relationship then equates:

$$
\mathrm{I}_{\mathrm{t}}=\mathrm{K}_{\mathrm{t}-1}-(1-\delta) \mathrm{K}_{\mathrm{t}}
$$

Where, $\delta$ is the rate of depreciation of physical capital. It is reasonable in developing economies like Sub-Saharan African countries to assume that a proportion (1- $\varphi$ ) of the flow of saving as the cost of financial intermediation, the saving investment identity for a closed economy with no government, takes the form of:

$$
\varphi \mathrm{S}_{\mathrm{t}}=\mathrm{I}_{\mathrm{t}}
$$

From Eq. 1, the relationship for the steady state growth rate is:

$$
g_{t+1}=\frac{Y_{t+1}}{Y_{t-1}}-1=\frac{K_{t+1}}{K_{t-1}}-1
$$

Therefore, financial intermediation by affecting the social marginal product of capital (A), the saving rate (s) and the share of saving which is invested $(\varphi)$, affects the growth rate of the economy. This can be specified as Eq. 5:

$$
\mathrm{g}=\mathrm{A} \frac{1}{\mathrm{y}}-\delta=\mathrm{A} \varphi \mathrm{s}-\delta
$$

Where, s represents the saving rate $\mathrm{S} / \mathrm{Y}$. Equation 5 reveals succinctly how development of financial intermediation can affect growth: it can raise $\varphi$, the proportion of saving funneled to investment it may increase $\mathrm{A}$, the social marginal productivity of capital and it can influence $s$, the private saving rate. According to Eq. 5, other things being equal, a country with a more efficient financial system is expected to have a higher growth rate. This indicates that the researchers can conduct the empirical work on the basis of Eq. 5 and by selecting financial variable; investigates the significance of financial development for economic growth. 


\section{MATERIALS AND METHODS}

Data description and sources: This study used secondary data (time series data). Empirical investigation was carried out on the basis of the sample covering the period 1970-2005. About 4 indicators of financial development were considered and one indicator of economic growth. The indicators of financial development considered are private credit, bank credit, liquid liabilities and broad money while per capita real GDP (Gross Domestic Product) used for growth indicator. Data on these variables were sourced for 10 selected Sub-Saharan Africa, namely: Benin, Burkina Faso, Burundi, Cameroon, Cote d'Ivoire, Ghana, Madagascar, Malawi, Mali and Nigeria. Per capita real GDP is measured by the ratio of real GDP to total population in each country selected for this study. Liquid liabilities are measured by the ratio of M3 to the GDP. Brad money is measured as a ratio of M2 to GDP. Private credit is proxied by domestic credit to private sector and bank credit is proxied by domestic credit provided by banking sector. All these variables were sourced from World Development Indicators (WDI), CD-ROM (2007) published by World Bank.

Specification of model: In this study, the method of Vector Error Correction Model (VECM) is adopted to estimate the effects of financial development indicators on economic growth. The choice of this approach is based on its various advantages over the conventional multivariate co-integration procedure. It is also adequate to capture the long run and short run relationship among variables. In order to test the causal relationships, the following multivariate model is to be estimated and following (Levine et al., 2000), the researchers consider the following variables as indicators of financial intermediary development:

$$
\mathrm{GDP}=\mathrm{f}(\mathrm{FD})
$$

Where, GDP is per capita real GDP. Economic growth is proxied by per capita real GDP while Financial Development (FD) is proxied by the following indicators:

Where:

$$
\mathrm{FD}=(\mathrm{PC}, \mathrm{BC}, \mathrm{LL}, \mathrm{M} 2)
$$

$\mathrm{PC}=$ Domestic credit to private sector as $\%$ of GDP

$\mathrm{BC}=$ Domestic credit provided by banking sector as $\%$ of GDP

$\mathrm{LL}=$ Liquid liabilities (M3) as \% of GDP

$\mathrm{M} 2=\mathrm{M} 2$ as $\%$ of GDP

Many researchers have used these variables as a measure of financial indicators. PC provides information about the financial institution credit allocated to private sector as compared with size of the economy as a whole and $\mathrm{BC}$ provides information about domestic credit provided by banking sector. LL indicates financial depth as well as M2 and do not represent effectiveness of the financial system.

Unit root tests: The preliminary investigation commenced with confirmation of the order of integration of the series where the series is confirmed to be order 1 then multiple co-integration can then be performed. Time series analysis involving stochastic trends, Augmented Dickey-Fuller and Philip Perron unit root tests are calculated for individual series to provide evidence as to whether the variables are integrated. This is followed by a multivariate co-integration analysis. Augmented Dickey-Fuller (ADF) and Philip Perron (PP) tests involve the estimation one of the following equations, respectively:

$$
\begin{gathered}
\Delta \mathrm{X}_{\mathrm{t}}=\beta \mathrm{X}_{\mathrm{t}-1}+\sum_{\mathrm{i}=1}^{\mathrm{n}} \delta_{\mathrm{i}} \Delta \mathrm{X}_{\mathrm{t}-\mathrm{i}}+\varepsilon_{\mathrm{t}} \\
\Delta \mathrm{X}_{\mathrm{t}}=\alpha_{0}+\beta \mathrm{X}_{\mathrm{t}-1}+\sum_{\mathrm{i}=1}^{\mathrm{n}} \delta_{\mathrm{i}} \Delta \mathrm{X}_{\mathrm{t}-\mathrm{i}}+\varepsilon_{\mathrm{t}} \\
\Delta \mathrm{X}_{\mathrm{t}}=\alpha_{0}+\alpha_{1} \mathrm{t}+\beta \mathrm{X}_{\mathrm{t}-1}+\sum_{\mathrm{i}=1}^{\mathrm{n}} \delta_{\mathrm{i}} \Delta \mathrm{X}_{\mathrm{t}-\mathrm{i}}+\varepsilon_{\mathrm{t}}
\end{gathered}
$$

The additional lagged terms are included to ensure that the errors are uncorrelated. The maximum lag length begins with 3 lags and proceeds down to the appropriate lag by examining the $\mathrm{AIC}$ and $\mathrm{SC}$ information criteria.

Johansen co-integration analysis: Since, it has been determined that the variables under examination are integrated of order 1 then the co-integrated test is performed. The testing hypothesis is the null of non-cointegration against the alternative that is the existence of co-integrated using the Johansen maximum likelihood procedure. The Johansen method applies the maximum likelihood procedure to determine the presence of cointegrated vectors in non-stationary time series.

Vector Error Correction Model (VECM): This study specifies and estimates VECM including the error correction term to investigate dynamic behaviour of the model. Once the equilibrium conditions are imposed, the VEC model describes the examined model is adjusting in each time period towards its long-run equilibrium state. Since, the variables are to be co-integrated then in the 
short-run, deviations from this long-run equilibrium will feed back on the changes in the dependent variables in order to force their movements towards the long-run equilibrium state. The VEC specification forces the long-run behaviour of the endogenous variables to converge to their co-integrated relationships while accommodates short-run dynamics. The size of the error correction term indicates the speed of adjustment of any disequilibrium towards a long-run equilibrium state. The final form of the Error Correction Model (ECM) was selected according to the approach suggested by Nzue (2006). The general form of the Vector Error Correction Model (VECM) is the following:

$$
\begin{aligned}
& \sum_{\mathrm{i}=0}^{\mathrm{n}} \delta_{1 \mathrm{i}} \Delta \mathrm{Y}_{\mathrm{t}-\mathrm{i}}+\sum_{\mathrm{i}=0}^{\mathrm{n}} \delta_{2 \mathrm{i}} \Delta \mathrm{F}_{\mathrm{t}-\mathrm{i}}+\sum_{\mathrm{i}=0}^{\mathrm{n}} \delta_{3 \mathrm{i}} \Delta \mathrm{B}_{\mathrm{t}-\mathrm{i}}+ \\
& \sum_{\mathrm{i}=0}^{\mathrm{n}} \delta_{4 \mathrm{i}} \Delta \mathrm{P}_{\mathrm{t}-\mathrm{i}}+\lambda_{1} \mathrm{ECM}_{\mathrm{t}-1}+\varepsilon_{\mathrm{t}} \\
\Delta \mathrm{F}_{\mathrm{t}}= & \gamma_{0}+\sum_{\mathrm{i}=0}^{\mathrm{n}} \gamma_{1 i} \Delta \mathrm{F}_{\mathrm{t}-\mathrm{i}}+\sum_{\mathrm{i}=0}^{\mathrm{n}} \gamma_{2 \mathrm{i}} \Delta \mathrm{Y}_{\mathrm{t}-\mathrm{i}}+\sum_{\mathrm{i}=0}^{\mathrm{n}} \gamma_{3 \mathrm{i}} \Delta \mathrm{B}_{\mathrm{t}-\mathrm{i}}+ \\
& \sum_{\mathrm{i}=0}^{\mathrm{n}} \gamma_{4 i} \Delta \mathrm{P}_{\mathrm{t}-\mathrm{i}}+\lambda_{2} \mathrm{ECM}_{\mathrm{t}-1}+\varepsilon_{\mathrm{t}}
\end{aligned}
$$

Where, $\mathrm{ECM}_{\mathrm{t}-1}$ is the error correction term. The coefficient of the ECM variable contains information about whether the past values of variables affect the current values of the variables under study. The size and statistical significance of the coefficient on the error correction term in each ECM model, measures the tendency of each variable to return to the equilibrium. A significant coefficient implies that past equilibrium errors play a role in determining the current outcomes. The short run dynamics are captured through the individual coefficients of the difference terms. Financial development (F) does not Granger cause economic growth (Y) if all $\delta_{2 \mathrm{i}}=0$ and economic growth $(\mathrm{Y})$ does not Granger cause financial development $(\mathrm{F})$ if all $\gamma_{2 \mathrm{i}}=0$. These hypotheses can be tested using standard F-statistics (Mehra, 1994).

Granger causality tests: Granger causality is used for testing the long-run relationship between financial development and economic growth. The Granger procedure is selected because it consists the more powerful and simpler way of testing causal relationship. The following model is estimated:

$$
\Delta \mathrm{Y}_{\mathrm{t}}=\alpha_{0}+\sum_{\mathrm{j}=1}^{\mathrm{k}} \alpha_{1 \mathrm{j}} \Delta \mathrm{Y}_{\mathrm{t}-\mathrm{j}}+\sum_{\mathrm{j}=1}^{\mathrm{k}} \alpha_{2 j} \Delta \mathrm{FD}_{\mathrm{t}-\mathrm{j}}+\mathrm{v}_{\mathrm{j}}
$$

$$
\Delta \mathrm{FD}_{\mathrm{t}}=\beta_{0}+\sum_{\mathrm{j}=1}^{\mathrm{k}} \beta_{1 \mathrm{ij}} \Delta \mathrm{FD}_{\mathrm{t}-\mathrm{j}}+\sum_{\mathrm{j}=1}^{\mathrm{k}} \beta_{2 \mathrm{j}} \Delta \mathrm{Y}_{\mathrm{t}-\mathrm{j}}+v_{\mathrm{j}}
$$

Where:

$Y_{t}=$ Proxy for economic growth

$\mathrm{FD}_{\mathrm{t}}=$ Proxy for financial development

$v_{j} \quad=$ A zero mean white noise error term

In order to test the above hypotheses, the usual Wald F-statistic test is utilized which has the following form:

$$
\mathrm{F}=\frac{\left(\mathrm{RSS}_{\mathrm{R}}-\mathrm{RSS}_{\mathrm{u}}\right) / \mathrm{q}}{\mathrm{RSS}_{\mathrm{u}} /(\mathrm{T}-2 \mathrm{q}-1)}
$$

Where:

$\mathrm{RSS}_{\mathrm{R}}=$ The sum of squared residuals from the equation under the assumption that a set of variables is redundant when the restrictions are imposed (restricted equation)

$\mathrm{RSS}_{u}=$ The sum of squared residuals from the complete (unrestricted) equation

$\mathrm{T}=$ The sample size

$\mathrm{q}=$ The lag length

The hypotheses in this test are:

$\mathrm{H}_{0}$ : FD does not Granger cause $Y$, i.e., $\left\{\alpha_{11}, \alpha_{12}, \ldots \ldots \alpha_{1 k}\right\}=0$ if $\mathrm{F}_{\mathrm{c}}<$ critical value of $\mathrm{F}$

$\mathrm{H}_{1}$ : FD does Granger cause $Y$, i.e., $\left\{\alpha_{11}, \alpha_{12}, \ldots \ldots \alpha_{1 \mathrm{k}}\right\} \neq 0$ if $\mathrm{F}_{\mathrm{c}}>$ critical value of $\mathrm{F}$

and

$\mathrm{H}_{0}$ : $\mathrm{Y}$ does not Granger cause FD, i.e., $\left\{\beta_{21}, \beta_{22}, \ldots \beta_{2 k}\right\}=0$ if $F_{c}<$ critical value of $F$

$\mathrm{H}_{1}$ : $\mathrm{Y}$ does Granger cause FD, i.e., $\left\{\beta_{21}, \beta_{22}, \ldots, \beta_{2 k}\right\} \neq 0$ if $F_{c}>$ critical value of $F$

The results related to the existence of Granger causal relationships among economic growth and financial development indicators.

Estimation technique: Per capita real GDP entered the estimation model in log form. The researachers perform a unit root test on each variable in the model using the Augmented Dickey-Fuller (ADF) tests.

With evidence of unit roots, the series are said to be integrated of order one -I(1) meaning that they must be modeled in first difference $\left(\Delta y_{t}=y_{t}-y_{t-1}\right)$ to make them stationary. A time series is stationary if it does not change overtime which implies that its values have constant variability. This enables us to avoid the problems of spurious regressions that are associated with non-stationary time series models (Table 1 and 2). 
Table 1: Augmented Dicky-Fuller unit root test

\begin{tabular}{|c|c|c|c|c|c|c|c|c|c|c|}
\hline \multirow[b]{2}{*}{ Variables } & \multicolumn{2}{|l|}{ Benin } & \multicolumn{2}{|c|}{ Burkina Faso } & \multicolumn{2}{|c|}{ Burundi } & \multicolumn{2}{|c|}{ Cameroon } & \multicolumn{2}{|c|}{ Cote d'Ivoire } \\
\hline & Level & $\begin{array}{c}\text { First } \\
\text { difference }\end{array}$ & Level & $\begin{array}{c}\text { First } \\
\text { difference }\end{array}$ & Level & $\begin{array}{c}\text { First } \\
\text { difference }\end{array}$ & Level & $\begin{array}{l}\text { First } \\
\text { difference }\end{array}$ & Level & $\begin{array}{c}\text { First } \\
\text { difference }\end{array}$ \\
\hline Gdp & -1.464 & $-4.532^{*}$ & -0.394 & $-6.125^{*}$ & -0.577 & $-3.197^{*}$ & -1.970 & $-2.972^{*}$ & -1.002 & $-3.240^{*}$ \\
\hline $\mathrm{Pc}$ & -1.349 & $-3.777^{*}$ & -2.546 & $-2.723^{* * *}$ & -1.040 & $-2.961^{*}$ & -1.062 & $-3.604^{*}$ & -0.472 & $-2.830^{\text {**t }}$ \\
\hline $\mathrm{Bc}$ & -1.233 & $-3.317^{*}$ & -2.463 & $-3.211^{*}$ & -0.608 & $-4.229^{*}$ & -1.518 & $-3.701^{*}$ & -1.006 & $-3.271^{*}$ \\
\hline Ll & -2.122 & $-4.003^{*}$ & -1.832 & $-5.948^{*}$ & -0.380 & $-5.246^{*}$ & -1.999 & $-5.212^{*}$ & -1.674 & $-4.742^{*}$ \\
\hline $\begin{array}{l}\text { Fd } \\
\text { p-values }\end{array}$ & -2.114 & $-4.223^{*}$ & -1.459 & $-5.643^{*}$ & -0.330 & $-4.210^{*}$ & -1.968 & $-3.262^{*}$ & -1.943 & $-4.971 *$ \\
\hline $1 \%$ & -2.949 & -3.642 & -3.635 & -3.642 & -3.635 & -3.642 & -3.635 & -3.642 & -3.635 & -3.642 \\
\hline $5 \%$ & -2.949 & -2.952 & -2.949 & -2.952 & -2.949 & -2.952 & -2.949 & -2.952 & -2.949 & -2.952 \\
\hline $10 \%$ & -2.613 & -2.614 & -2.613 & -2.614 & -2.613 & -2.614 & -2.613 & -2.614 & -2.613 & -2.614 \\
\hline
\end{tabular}

$*$ and ${ }^{* *}$ indicate the level of significance at 5 and $10 \%$, respectively

Table 2: Augmented Dicky-Fuller unit root test

\begin{tabular}{|c|c|c|c|c|c|c|c|c|c|c|}
\hline \multirow[b]{2}{*}{ Variables } & \multicolumn{2}{|l|}{ Ghana } & \multicolumn{2}{|c|}{ Madagascar } & \multicolumn{2}{|l|}{ Malawi } & \multicolumn{2}{|l|}{ Mali } & \multicolumn{2}{|l|}{ Nigeria } \\
\hline & Level & $\begin{array}{c}\text { First } \\
\text { difference }\end{array}$ & Level & $\begin{array}{l}\text { First } \\
\text { difference }\end{array}$ & Level & $\begin{array}{c}\text { First } \\
\text { difference }\end{array}$ & Level & $\begin{array}{c}\text { First } \\
\text { difference }\end{array}$ & Level & $\begin{array}{l}\text { First } \\
\text { difference }\end{array}$ \\
\hline Gdp & -1.492 & $-3.460^{*}$ & -2.603 & $-4.821^{*}$ & -2.032 & $-3.814 *$ & -0.813 & $-4.032^{*}$ & -1.255 & $-3.747^{*}$ \\
\hline Pc & -0.767 & $-4.577^{*}$ & -1.315 & $-4.271^{*}$ & -1.477 & $-3.253 *$ & -2.250 & $-4.359^{*}$ & -1.884 & $-3.843^{*}$ \\
\hline $\mathrm{Bc}$ & -2.137 & $-3.744^{*}$ & -1.761 & $-3.487^{*}$ & -1.622 & $-3.765^{*}$ & -1.111 & $-5.070^{*}$ & -1.836 & $-3.265^{*}$ \\
\hline Ll & -0.954 & $-3.884^{*}$ & -2.656 & $-5.820^{*}$ & $-3.298^{*}$ & $-4.803^{*}$ & -0.889 & $-5.256^{*}$ & -2.187 & $-2.965^{*}$ \\
\hline $\begin{array}{l}\mathrm{Fd} \\
\mathrm{p} \text {-values }\end{array}$ & -0.456 & $-4.079^{*}$ & -2.306 & $-4.354^{*}$ & -2.141 & $-3.998^{*}$ & -1.135 & $-4.837^{*}$ & -2.033 & $-3.097^{*}$ \\
\hline $1 \%$ & -3.635 & -3.642 & -3.635 & -3.642 & -3.635 & -3.642 & -3.635 & -3.642 & -3.635 & -3.642 \\
\hline $5 \%$ & -2.949 & -2.952 & -2.949 & -2.952 & -2.949 & -2.952 & -2.949 & -2.952 & -2.949 & -2.952 \\
\hline $10 \%$ & -2.613 & -2.614 & -2.613 & -2.614 & -2.613 & -2.614 & -2.613 & -2.614 & -2.613 & -2.614 \\
\hline
\end{tabular}

After testing for unit roots, the researchers proceed to test for co-integration (long run relationship between variables).

This study will concentrate on Johansen and Juselius (1991)'s definition of co-integration. Johansen's co-integration procedure will be used to test for the possibility of at least one co-integrating vector between variables in all the models developed for each of the Sub-Saharan African countries included in this study.

\section{RESULTS AND DISCUSSION}

The results of the co-integration test are shown in Table 3 and it shows that there was at least one co-integration relationship among the variables in the model for all the selected countries in Sub-Saharan Africa.

The evidence of multivariate co-integration test results suggests that financial development and economic growth are co-integrated. That is these variables move together in the long run. Results of the ECTs as well as the Granger causality tests are shown in Table 4 and 5. Since, the error correction representation can be used to test for Granger causality, the researchers estimated both Eq. 9 and 10 .

It shows from these results that the error correction terms in both equations are well defined that is their associated coefficients are negative and statistically significant at $5 \%$. The result supports the findings of
Table 3: Co-integration tests for 10 countries

\begin{tabular}{llllc}
\hline Country & $\mathrm{r}=0$ & $\mathrm{r} \leq 1$ & $\mathrm{r} \leq 2$ & $\mathrm{r} \leq 3$ \\
\hline Benin & $105.36^{*}$ & $68.23^{*}$ & $36.91^{*}$ & 9.85 \\
Burkina Faso & $156.32^{*}$ & $99.65^{*}$ & $57.45^{*}$ & $29.29^{*}$ \\
Burundi & $138.56^{*}$ & $60.57^{*}$ & 29.15 & 6.47 \\
Cameroon & $145.95^{*}$ & $76.03^{*}$ & $38.84^{*}$ & $18.86^{*}$ \\
Cote d'Ivoire & $155.26^{*}$ & $86.19^{*}$ & $42.47^{*}$ & 15.13 \\
Ghana & $82.93^{*}$ & $50.09^{*}$ & 26.11 & 9.24 \\
Madagascar & $116.55^{*}$ & $67.19^{*}$ & $40.81^{*}$ & $19.54^{*}$ \\
Malawi & $124.93^{*}$ & $70.00^{*}$ & $38.47^{*}$ & $16.21^{*}$ \\
Mali & $109.16^{*}$ & $57.41^{*}$ & 28.23 & 7.21 \\
Nigeria & $70.81^{*}$ & $87.24^{*}$ & $45.37^{*}$ & 14.23 \\
\hline * indicates the level of significance at $5 \% ;$ Maximal eigenvalue statistics \\
under the. HO: rank $=\mathrm{r}$
\end{tabular}

Athanasios and Antonoios (2009). The coefficient ranges from -0.017 to -0.497 in growth equation of the model while ranges from -0.010 to -0.950 for finance equation of the model in all the selected Sub-Saharan African countries. This indicates a feedback of approximately $49 \%$ (for growth equation) of the previous year's disequilibrium and a feedback of approximately $95 \%$ (for the finance equation) of the previous year's disequilibrium for all the significance of the coefficient on ECT supports the conclusion of co-integration. This finding contradicts the empirical evidence of Deidda and Fattouh (2002) and Xu (2000) and supports the studies of McKinnon (1973) and Luintel and Khan (1999). The short run dynamics are captured by the individual parameters except that of the ECT term. The evidence of unidirectional causality found in Benin, Burkina Faso, 
J. Econ. Theroy, 4 (2): 50-58, 2010

Table 4: Multivariate Granger causality and VECM

\begin{tabular}{|c|c|c|c|c|c|c|c|c|c|c|}
\hline \multirow[b]{2}{*}{ Variables } & \multicolumn{2}{|l|}{ Benin } & \multicolumn{2}{|c|}{ Burkina Faso } & \multicolumn{2}{|l|}{ Burundi } & \multicolumn{2}{|l|}{ Cameroon } & \multicolumn{2}{|c|}{ Cote d'Ivoire } \\
\hline & $\begin{array}{l}\text { Growth } \\
\text { equation }\end{array}$ & $\begin{array}{l}\text { Finance } \\
\text { equation }\end{array}$ & $\begin{array}{l}\text { Level } \\
\text { equation }\end{array}$ & $\begin{array}{l}\text { difference } \\
\text { equation }\end{array}$ & $\begin{array}{l}\text { Growth } \\
\text { equation }\end{array}$ & $\begin{array}{l}\text { Finance } \\
\text { equation }\end{array}$ & $\begin{array}{l}\text { Growth } \\
\text { equation }\end{array}$ & $\begin{array}{l}\text { Finance } \\
\text { equation }\end{array}$ & $\begin{array}{l}\text { Growth } \\
\text { equation }\end{array}$ & $\begin{array}{l}\text { Finance } \\
\text { equation }\end{array}$ \\
\hline Constant & $\begin{array}{l}-0.564 \\
(-0.172)\end{array}$ & $\begin{array}{l}-0.700 \\
(-0.540)\end{array}$ & $\begin{array}{l}0.015 \\
(1.654)\end{array}$ & $\begin{array}{l}-0.748 \\
(-1.862)\end{array}$ & $\begin{array}{l}0.010 \\
(0.934)\end{array}$ & $\begin{array}{l}0.237 \\
(1.246)\end{array}$ & $\begin{array}{l}0.008 \\
(0.788)\end{array}$ & $\begin{array}{l}-0.284 \\
(-0.566)\end{array}$ & $\begin{array}{l}-0.012 \\
(-1.587)\end{array}$ & $\begin{array}{l}0.442 \\
(0.688)\end{array}$ \\
\hline$\Delta \mathrm{GDP}_{\mathrm{t}}$ & - & $\begin{array}{l}0.062^{*} \\
(2.213)\end{array}$ & - & $\begin{array}{l}0.033^{*} \\
(6.701)\end{array}$ & - & $\begin{array}{l}0.407 \\
(1.453)\end{array}$ & - & $\begin{array}{l}0.387^{*} \\
(2.084)\end{array}$ & - & $\begin{array}{l}0.903^{*} \\
(2.416)\end{array}$ \\
\hline$\Delta \mathrm{GDP}_{\mathrm{t}-1}$ & $\begin{array}{l}0.559^{*} \\
(2.074)\end{array}$ & $\begin{array}{l}-0.176^{*} \\
(-1.996)\end{array}$ & $\begin{array}{l}-0.008 \\
(-0.024)\end{array}$ & $\begin{array}{l}0.548^{*} \\
(2.965)\end{array}$ & $\begin{array}{l}-0.062 \\
(-0.305)\end{array}$ & $\begin{array}{l}-0.707 \\
(-0.385)\end{array}$ & $\begin{array}{l}0.329 \\
(1.488)\end{array}$ & $\begin{array}{l}-0.531 \\
(-0.049)\end{array}$ & $\begin{array}{l}0.118 \\
(0.604)\end{array}$ & $\begin{array}{l}0.802 \\
(0.468)\end{array}$ \\
\hline$\Delta \mathrm{FD}_{\mathrm{t}}$ & $\begin{array}{l}-0.448 \\
(-1.116)\end{array}$ & - & $\begin{array}{l}-0.019 \\
(-1.475)\end{array}$ & - & $\begin{array}{l}0.002 \\
(-0.225)\end{array}$ & - & $\begin{array}{l}0.001 \\
(0.102)\end{array}$ & - & $\begin{array}{l}-0.254 \\
(-0.557)\end{array}$ & - \\
\hline$\Delta \mathrm{FD}_{\mathrm{t}-1}$ & $\begin{array}{l}-0.084^{*} \\
(8.491)\end{array}$ & $\begin{array}{l}0.890 \\
(1.279)\end{array}$ & $\begin{array}{l}-0.042^{*} \\
(-2.284)\end{array}$ & $\begin{array}{l}-0.662^{*} \\
(-2.021)\end{array}$ & $\begin{array}{l}-0.022 \\
(-1.026)\end{array}$ & $\begin{array}{l}-0.665 \\
(-0.344)\end{array}$ & $\begin{array}{l}0.007 \\
(0.291)\end{array}$ & $\begin{array}{l}0.978 \\
(0.834)\end{array}$ & $\begin{array}{l}0.006 \\
(0.535)\end{array}$ & $\begin{array}{l}-0.915 \\
(-0.943)\end{array}$ \\
\hline$\Delta \mathrm{Bc}_{\mathrm{t}-1}$ & $\begin{array}{l}0.004 * \\
(1.988)\end{array}$ & $\begin{array}{l}0.005 \\
(1.346)\end{array}$ & $\begin{array}{l}-0.008 \\
(-0.993)\end{array}$ & $\begin{array}{l}-0.820 \\
(-2.068)\end{array}$ & $\begin{array}{l}0.005 \\
(0.141)\end{array}$ & $\begin{array}{l}-0.400 \\
(-1.175)\end{array}$ & $\begin{array}{l}-0.010^{*} \\
(-2.111)\end{array}$ & $\begin{array}{l}-0.920^{*} \\
(-3.649)\end{array}$ & $\begin{array}{l}0.002 \\
(0.591)\end{array}$ & $\begin{array}{l}-0.603 \\
(-1.635)\end{array}$ \\
\hline$\Delta \mathrm{Pc}_{\mathrm{t}-1}$ & $\begin{array}{l}-0.002 \\
(-1.297)\end{array}$ & $\begin{array}{l}0.672 \\
(1.899)\end{array}$ & $\begin{array}{l}0.012 \\
(1.654)\end{array}$ & $\begin{array}{l}0.113^{*} \\
(3.348)\end{array}$ & $\begin{array}{l}-0.005 \\
(-1.011)\end{array}$ & $\begin{array}{l}0.163 \\
(0.335)\end{array}$ & $\begin{array}{l}0.001 \\
(0.189)\end{array}$ & $\begin{array}{l}-0.043 \\
(-0.162)\end{array}$ & $\begin{array}{l}0.007 \\
(1.460)\end{array}$ & $\begin{array}{l}0.078 \\
(0.176)\end{array}$ \\
\hline$\Delta \mathrm{Ll}_{\mathrm{t}-1}$ & $\begin{array}{l}0.080^{*} \\
(8.064)\end{array}$ & $\begin{array}{l}0.015 \\
(1.222)\end{array}$ & $\begin{array}{l}0.029^{*} \\
(2.174)\end{array}$ & $\begin{array}{l}0.380^{*} \\
(2.290)\end{array}$ & $\begin{array}{l}0.005 \\
(0.519)\end{array}$ & $\begin{array}{l}-0.062 \\
(-0.070)\end{array}$ & $\begin{array}{l}0.025 \\
(1.737)\end{array}$ & $\begin{array}{l}0.612^{*} \\
(2.244)\end{array}$ & $\begin{array}{l}-0.022 \\
(-1.921)\end{array}$ & $\begin{array}{l}1.738 \\
(1.729)\end{array}$ \\
\hline $\mathrm{ECT}_{\mathrm{t}-1}$ & $\begin{array}{l}-0.353^{*} \\
(-1.972)\end{array}$ & $\begin{array}{l}-0.062^{*} \\
(-2.213)\end{array}$ & $\begin{array}{l}-0.497^{*} \\
(-2.403)\end{array}$ & $\begin{array}{l}-0.010^{*} \\
(-1.985)\end{array}$ & $\begin{array}{l}-0.406^{*} \\
(-1.984)\end{array}$ & $\begin{array}{l}-0.950^{*} \\
(-1.995)\end{array}$ & $\begin{array}{l}-0.118^{*} \\
(-3.798)\end{array}$ & $\begin{array}{l}-0.248^{*} \\
(-2.739)\end{array}$ & $\begin{array}{l}-0.299^{*} \\
(-2.303)\end{array}$ & $\begin{array}{l}0.219^{*} \\
(-2.543)\end{array}$ \\
\hline $\mathrm{R}^{2}$ adjusted & 0.49 & 0.50 & 0.42 & 0.66 & 0.46 & 0.51 & 0.49 & 0.57 & 0.53 & 0.43 \\
\hline $\begin{array}{l}\text { F-stat } \\
\text { F-stat: }\end{array}$ & $1.89^{*}$ & $1.91^{*}$ & $3.85^{*}$ & $2.13^{*}$ & $1.67^{*}$ & $2.02^{*}$ & $1.88^{*}$ & $2.59^{*}$ & $2.22^{*}$ & $1.46^{*}$ \\
\hline $\begin{array}{l}\text { i.Finance } \\
\text { * growth }\end{array}$ & 1.92 & - & $2.72^{* * * *}$ & - & $5.24 *$ & - & $3.14^{* * *}$ & - & $5.68^{*}$ & - \\
\hline $\begin{array}{l}\text { ii. Growth } \\
\text { ₹ finance }\end{array}$ & - & $2.89^{* * *}$ & - & $4.90^{*}$ & - & 0.89 & 1.67 & - & $14.77^{*}$ & - \\
\hline
\end{tabular}

$*$ and ${ }^{* * *}$ indicate the level of signific ance at 5 and $10 \%$, respectively. Numbers in parentheses are t-statistic

Table 5: Multivariate Granger causality and VECM

\begin{tabular}{|c|c|c|c|c|c|c|c|c|c|c|}
\hline \multirow[b]{2}{*}{ Variables } & \multicolumn{2}{|l|}{ Ghana } & \multicolumn{2}{|c|}{ Madagascar } & \multicolumn{2}{|l|}{ Malawi } & \multicolumn{2}{|l|}{ Mali } & \multicolumn{2}{|l|}{ Nigeria } \\
\hline & $\begin{array}{l}\text { Growth } \\
\text { equation }\end{array}$ & $\begin{array}{l}\text { Finance } \\
\text { equation }\end{array}$ & $\begin{array}{l}\text { Level } \\
\text { equation }\end{array}$ & $\begin{array}{l}\text { difference } \\
\text { equation }\end{array}$ & $\begin{array}{l}\text { Growth } \\
\text { equation }\end{array}$ & $\begin{array}{l}\text { Finance } \\
\text { equation }\end{array}$ & $\begin{array}{l}\text { Growth } \\
\text { equation }\end{array}$ & $\begin{array}{l}\text { Finance } \\
\text { equation }\end{array}$ & $\begin{array}{l}\text { Growth } \\
\text { equation }\end{array}$ & $\begin{array}{l}\text { Finance } \\
\text { equation }\end{array}$ \\
\hline Constant & $\begin{array}{l}-0.002 \\
(-0.391)\end{array}$ & $\begin{array}{l}0.027 \\
(0.043)\end{array}$ & $\begin{array}{l}-0.026^{*} \\
(-2.709)\end{array}$ & $\begin{array}{l}-0.175 \\
(-0.279)\end{array}$ & $\begin{array}{l}0.004 \\
(0.421)\end{array}$ & $\begin{array}{l}0.307 \\
(0.304)(1.65\end{array}$ & $\begin{array}{l}0.017 \\
55)\end{array}$ & $\begin{array}{l}-0.940 \\
(-1.391)\end{array}$ & $\begin{array}{l}-0.025^{*} \\
(-4.574)\end{array}$ & $\begin{array}{l}-0.554 \\
(-0.465)\end{array}$ \\
\hline$\Delta \mathrm{GDP}_{\mathrm{t}}$ & - & $\begin{array}{l}0.283 \\
(1.678)\end{array}$ & - & $\begin{array}{l}-0.334 \\
(0.178)\end{array}$ & - & $\begin{array}{l}-0.071 \\
(-0.256)\end{array}$ & - & $\begin{array}{l}0.111 \\
(0.644)\end{array}$ & - & $\begin{array}{l}-0.021 \\
(-0.093)\end{array}$ \\
\hline$\Delta \mathrm{GDP}_{\mathrm{t}-1}$ & $\begin{array}{l}0.207 \\
(1.105)\end{array}$ & $\begin{array}{l}0.732 \\
(1.926)\end{array}$ & $\begin{array}{l}-0.403 \\
(-1.693)\end{array}$ & $\begin{array}{l}0.542 \\
(0.166)\end{array}$ & $\begin{array}{l}-0.132 \\
(-0.499)\end{array}$ & $\begin{array}{l}0.122^{*} \\
(2.585)\end{array}$ & $\begin{array}{l}-0.110 \\
(-0.646)\end{array}$ & $\begin{array}{l}-0.788 \\
(-0.325)\end{array}$ & $\begin{array}{l}-0.153 \\
(-0.532)\end{array}$ & $\begin{array}{l}0.057 \\
(0.289)\end{array}$ \\
\hline$\Delta \mathrm{Fd}_{\mathrm{t}}$ & $\begin{array}{l}0.337 \\
(0.245)\end{array}$ & - & $\begin{array}{l}0.014 \\
(1.823)\end{array}$ & - & $\begin{array}{l}-0.003 \\
(-0.351)\end{array}$ & - & $\begin{array}{l}-0.006 \\
(-0.469)\end{array}$ & - & $\begin{array}{l}0.741 \\
(1.508)\end{array}$ & - \\
\hline$\Delta \mathrm{Fd}_{\mathrm{t}-1}$ & $\begin{array}{l}0.034^{*} \\
(2.089)\end{array}$ & $\begin{array}{l}-0.820^{*} \\
(-3.280)\end{array}$ & $\begin{array}{l}-0.015 \\
(-1.604)\end{array}$ & $\begin{array}{l}0.697 \\
(1.157)\end{array}$ & $\begin{array}{l}-0.006 \\
(-0.410)\end{array}$ & $\begin{array}{l}0.830^{*} \\
(2.922)\end{array}$ & $\begin{array}{l}-0.017 \\
(-1.183)\end{array}$ & $\begin{array}{l}-0.360 \\
(-0.239)\end{array}$ & $\begin{array}{l}0.415 \\
(1.712)\end{array}$ & $\begin{array}{l}0.422 \\
(0.616)\end{array}$ \\
\hline$\Delta \mathrm{Bc}_{\mathrm{t}-1}$ & $\begin{array}{l}-0.001 \\
(-0.672)\end{array}$ & $\begin{array}{l}0.413 \\
(1.857)\end{array}$ & $\begin{array}{l}-0.002 \\
(-0.482)\end{array}$ & $\begin{array}{l}0.607^{*} \\
(2.244)\end{array}$ & $\begin{array}{l}0.009 \\
(0.294)\end{array}$ & $\begin{array}{l}-0.001 \\
(-0.616)\end{array}$ & $\begin{array}{l}0.004 \\
(1.242)\end{array}$ & $\begin{array}{l}-0.197 \\
(-0.541)\end{array}$ & $\begin{array}{l}0.003 \\
(1.070)\end{array}$ & $\begin{array}{l}0.326 \\
(0.913)\end{array}$ \\
\hline$\Delta \mathrm{Pc}_{\mathrm{t}-1}$ & $\begin{array}{l}-0.004 \\
(-0.637)\end{array}$ & $\begin{array}{l}0.238^{*} \\
(3.412)\end{array}$ & $\begin{array}{l}-0.003 \\
(-0.157)\end{array}$ & $\begin{array}{l}0.085^{*} \\
(1.997)\end{array}$ & $\begin{array}{l}0.005 \\
(0.862)\end{array}$ & $\begin{array}{l}0.643^{*} \\
(2.388)\end{array}$ & $\begin{array}{l}-0.002 \\
(-0.393)\end{array}$ & $\begin{array}{l}0.625 \\
(1.045)\end{array}$ & $\begin{array}{l}-0.352 \\
(-0.597)\end{array}$ & $\begin{array}{l}-0.324 \\
(-0.394)\end{array}$ \\
\hline$\Delta \mathrm{Ll}_{\mathrm{t}-1}$ & $\begin{array}{l}-0.023 \\
(-1.720)\end{array}$ & $\begin{array}{l}0.024^{*} \\
(3.354)\end{array}$ & $\begin{array}{l}0.012^{*} \\
(2.890)\end{array}$ & $\begin{array}{l}-0.605^{*} \\
(-2.168)\end{array}$ & $\begin{array}{l}-0.005 \\
(-0.691)\end{array}$ & $\begin{array}{l}-0.973 \\
(-1.169)\end{array}$ & $\begin{array}{l}-0.005 \\
(-0.584)\end{array}$ & $\begin{array}{l}0.318 \\
(1.325)\end{array}$ & $\begin{array}{l}-0.013 \\
(-1.742)\end{array}$ & $\begin{array}{l}-0.102 \\
(-0.349)\end{array}$ \\
\hline $\mathrm{ECT}_{\mathrm{t}-1}$ & $\begin{array}{l}-0.017^{*} \\
(-1.961)\end{array}$ & $\begin{array}{l}-0.240^{*} \\
(-1.994)\end{array}$ & $\begin{array}{l}-0.060^{*} \\
(-7.991)\end{array}$ & $\begin{array}{l}-0.040^{*} \\
(-4.974)\end{array}$ & $\begin{array}{l}-0.021^{*} \\
(-1.985)\end{array}$ & $\begin{array}{l}-0.093^{*} \\
(-1.976)\end{array}$ & $\begin{array}{l}-0.081^{*} \\
(-2.545)\end{array}$ & $\begin{array}{l}-0.060^{*} \\
(-2.211)\end{array}$ & $\begin{array}{l}-0.025^{*} \\
(-4.574)\end{array}$ & $\begin{array}{l}-0.031^{*} \\
(-6.236)\end{array}$ \\
\hline $\mathrm{R}^{2}$ adjusted & 0.54 & 0.56 & 0.42 & 0.61 & 0.52 & 0.55 & 0.58 & 0.43 & 0.47 & 0.49 \\
\hline $\begin{array}{l}\text { F-stat } \\
\text { F-stat: }\end{array}$ & $2.29^{*}$ & $2.45^{*}$ & $2.99^{*}$ & $2.41^{*}$ & $2.14^{*}$ & $2.11^{*}$ & $2.64^{*}$ & $1.77^{*}$ & $1.71^{*}$ & $1.86^{*}$ \\
\hline $\begin{array}{l}\text { i.Finance } \\
\text { ₹ growth }\end{array}$ & $4.19^{*}$ & - & 1.66 & - & 0.29 & - & $4.02^{*}$ & - & $5.36^{*}$ & - \\
\hline $\begin{array}{l}\text { ii. Growth } \\
\text { ₹ finance }\end{array}$ & - & $4.91^{*}$ & - & $6.49^{*}$ & - & $6.16^{*}$ & - & 0.69 & - & $3.80^{* * * *}$ \\
\hline
\end{tabular}

Burundi, Cameroon, Madagascar, Malawi, Mali and Nigeria. The findings from Table 4 and 5 show that financial development Granger causes economic growth in Burundi, Cameroon, Mali and Nigeria it provides support for the findings of Abu-Bader and Abu-Quan (2005) while economic growth Granger causes financial development in Benin, Burkina Faso, Madagascar and Malawi. This indicates that financial 
development promotes economic growth in Burundi, Cameroon, Mali and Nigeria while economic growth promotes financial development in Benin, Burkina Faso, Madagascar and Malawi. This finding provides support for unidirectional causality. This result gives support for the study of Athanasios and Antonoios (2009). The bidirectional causality found in Cote d'Ivoire and Ghana, the result shows that financial development and economic growth Granger cause one another. This indicates that financial development and economic growth promotes one another in the countries.

This finding provides support for Luintel and Khan (1999) and Patrick (1966). The findings show that individual coefficients of financial development indicators and per capita real output are negatively and insignificant related in most of the countries.

\section{CONCLUSION}

This study investigates the long run and causal relationship between financial development and economic growth for 10 Sub-Saharan African countries using multivariate Granger causality test within the context of VECM framework. Long run co-integrating relationship among the series could be detected for all the countries as well as direction of causality for effective policy making. Granger causality test within the VECM framework shows unidirectional relations running from financial development to economic growth in Burundi, Cameroon, Mali and Nigeria while running from economic growth to financial development in Benin, Burkina Faso, Madagascar and Malawi. However, within the same framework, the result shows bidirectional causality between financial development and economic growth in Cote d'Ivoire and Ghana.

This study has explored the long run and causal relationship between economic growth and financial development. The results suggest that financial development could contribute significantly to growth of all the selected countries in Sub-Saharan Africa. This implies that financial development could provide the necessary impetus to economic growth in the countries. In countries where evidence shows unidirectional Granger causality running from financial development to economic growth, efforts must be made to enhance improvement and efficiency of the markets which in turn accelerate economic growth of the countries.

However in country, where Granger causality runs from economic growth to financial development, the government of the country has to intensify efforts on policies that will enhance growth which in turn improve financial sector development of the economy. Moreover, in countries where the evidence of bi-directional causality between financial development and economic growth was found, policies have to be designed to enhance efficiency of the financial markets and economic growth.

Such policies could entail consolidation and improvement on current growth and investment patterns in these economies to improve development of financial markets which in turn will engender economic growth.

\section{RECOMMENDATIONS}

It is suggested that the impact of financial development on growth differs among countries in the region also the transmission mechanism differs. This also brings to fore the importance of time series researach as against panel estimation where specific country characteristics may not be succinctly seen.

\section{REFERENCES}

Abu-Bader, S. and A.M. Abu-Quan, 2005. Financial development and economic growth: Time series evidence Discussion Paper No. 05-14, Monaster Centre for Economic Research, Ben-Gurion University of Negev, Israel. http:/www.ec.bgu.ac. il/monaster/admin/papers/206.pdf.

Al-Yousif, Y.K., 2002. Financial development and economic growth: Another look at the evidence from developing countries. Rev. Financial Econ., 11: $131-150$.

Arestis, P., P. Demetriades and K. Luinted, 2001. Financial development and economic growth: The role of stock markets. J. Money Credit Bank, 33: 16-41.

Arrow, K.J., 1964. The role of securities in optimal allocation of risk bearing. Rev. Econ. Stud., 31: 91-96.

Athanasios, V. and A. Antonoios, 2009. Financial development and economic growth: An empirical analysis for Greece. Am. J. Applied Sci., 6: 1410-1417.

Boyd, J. and E. Prescott, 1986. Financial intermediation coalitions. J. Econ. Theory, 38: 211-232.

Chandavarkar, A., 1992. Of finance and development: Neglected and unsettled questions. World Dev., 22: $133-142$.

Debreu, G., 1959. Theory of Value. Wiley Inc., New York.

Deidda, L. and B. Fattouh, 2002. Non-linearity between finance and growth. Econ. Lett., 74: 339-345.

Diamond, D.W., 1984. Financial intermediation and delegated monitoring. Rev. Econ. Stud., 51: 393-414.

Fry, M.J., 1988. Money, Interest and Banking in Economic Development. John Hopkins University Press, London.

Galbis, V., 1977. Financial intermediation and economic growth in less developed countries: A theoretical approach. J. Dev. Stud., 13: 58-72. 
Goldsmith, R., 1969. Financial Structure and Development. 1st Edn., Yale University Press, New Haven, ISBN-10: 0300011709 , pp: 561

Gurley, J.G. and E.S. Shaw, 1955. Financial aspects of economic development. Am. Econ. Rev., 45: 515-538.

Khan, A.H. and L. Hassan, 1998. Financial liberalization, savings and economic development in Pakistian. Econ. Dev. Cultural Change, 46: 581-597.

King, R.G. and R. Levine, 1993. Financial and growth: Schumpeter might be right. Q. J. Monetary Econ., 108: 717-737.

Levine, R. and D. Renelt, 1992. A sensitivity analysis of cross-country growth regressions. Am. Econ. Rev., 82: $942-963$.

Levine, R. and S. Zervos, 1998. Stock markets, banks, and economic growth. Am. Econ. Rev., 88: 537-558.

Levine, R., 1997. Financial development and economic growth: Views and agenda. J. Econ. Literature, 35: 688-726.

Levine, R., N. Loyaza and T. Beck, 2000. Financial intermediation and growth: Causality and causes. J. Monetary Econ., 46: 31-77.

Lucas, R.E., 1988. On the mechanics of economic development. J. Monet. Econ., 22: 3-42.

Luintel, K.B. and M. Khan, 1999. A quantitative reassessment of the finance-growth nexus: Evidence from a multivariate VAR. J. Dev. Econ., 60: 381-405.

Mathieson, D.J., 1980. Financial reform and stabilization policy in a developing economy. J. Dev. Econ., 7: 359-395.

McKinnon, R.I., 1973. Money and Capital in Economic Development. 1st Edn., Brookings Institution, Washington DC. USA., ISBN-10: 0815756135, pp: 177.

Mehra, P.Y., 1994. Wage Growth and the Inflation Process: An Empirical Approach. In: Cointegration for the Applied Economist, Rao, B.B. (Ed.). St. Martin's Press, New York.

Neusser, K. and M. Kugler, 1998. Manufacturing growth and financial development: Evidence from OECD countries. Rev. Econ. Stat., 80: 638-646.
Nzue, F.F., 2006. Stock market development and economic growth: Evidence from Cote D'Ivoire. Afr. Dev. Rev., 18: 123-143.

Odhiambo, N.M., 2008. Financial depth, savings and economic growth in Kenya: A dynamic causal linkage. Econ. Modell., 25: 704-713.

Pagano, M., 1993. Financial markets and growth an overview European. Econ. Rev., 37: 613-622.

Patrick, H., 1966. Financial development and economic growth in underdeveloped countries. Econ. Dev. Cult. Change, 14: 174-189.

Rioja, F. and N. Valev, 2003. Does one size fit all: A reexamination of the finance-growth relationship. J. Dev. Econ., 74: 429-447.

Robinson, J., 1952. The Civilizations of the General Theory in the Rate of Interest and Other Essay. Macmillan Press, London.

Romer, D., 2001. Advanced Macroeconomics. McGraw Hill, New York.

Roubini, N. and X. Sala-i-Martin, 1992. Financial repression and economic growth. J. Dev. Econ., 39: $5-30$.

Schumpeter, J.A., 1911. The Theory of Economic Development. Harvard University Press, Cambridge.

Shaw, E., 1973. Financial Deepening in Economic Development. Oxford University Press, New York, USA.

Townsend, R.M., 1979. Optimal contracts and competitive markets with costly state verification. J. Econ. Theory, 21: 265-293.

Wolde-Rufael, Y., 2009. Re-examining the financial development and economic growth nexus in Kenya. Econ. Modell., 26: 1140-1146.

$\mathrm{Xu}, \mathrm{Z}$., 2000. Financial development, investment and growth. Econ. Inquiry, 38: 331-344. 